\title{
PERBANDINGAN METODE RECOVERY AKTIF DAN METODE CORSTABILITY TERHADAP KADAR ASAM LAKTAT
}

\author{
Buyung Kusumawardhana \\ Jurusan Pendidikan Jasmani Kesehatan dan Rekreasi, Universitas PGRI Semarang, Semarang, Indonesia \\ *buyungkusumawardhana@upgris.ac.id
}

(Received: July 2018 / Revised: September 2018 / Accepted: September 2018)

\begin{abstract}
ABSTRAK : Selain model latihan, recovery yang disebabkan karena meningkatknya konsentrasi kadar asam laktat merupakan bagian yang paling penting. Beberapa metode recovery yang baik, cepat dan mudah adalah metode recovery aktif dan metode corstability. Selain itu belum diketahuinya mana metode yang paling efektif antara recovery aktif dan metode corstability. Tujuan penelitian ini adalah untuk membandingkan metode recovery aktif dan metode corstability terhadap penurunan kadar asam laktat darah. Penelitian ini menggunakan metode penelitian eksperimental laboratoris dengan hasil diambil dari perlakuan secara akut. Sedangkan rancangan penelitian menggunakan Randomized Pretest-Postes Control Group Design. Hasil dari penelitian diperoleh bahwa metode recovery aktif lebih baik dibandingkan dengan metode corstability. Data yang diperoleh adalah kelompok recovery aktif dengan selisih $5,3 \mathrm{mmol} / \mathrm{L}$ sedangkan kelompok dengan metode corstability dengan selisih 4,32 mmol/L.

KATA KUNCI :

Recovery Aktif, Corstability, Kadar Asam Laktat.
\end{abstract}

ABSTRACTS : The objective of this study was to compare active recovery methods and to decrease blood lactate acid levels after performing submaximal physical activity. This study used a type of laboratory experimental study with results taken from acute treatment. While the research design using Randomized Pretest-Postes Control Group Design. The result of this research shows that active recovery method is better than method. The data obtained were active recovery group with difference of $5.3 \mathrm{mmol} / \mathrm{L}$ while group with corstability method with difference $4,32 \mathrm{mmol} / \mathrm{L}$.

\section{PENDAHULUAN}

Aktivitas fisik dapat berdampak positif dan juga dapat berdampak negatif terhadap seseorang yang melakukannya. Salah satu dampak negatif adalah terjadinya kerusakan jaringan di dalam tubuh. Umumnya kerusakan jaringan terjadi ketika seseorang dalam kondisi kelelahan. Aktivitas fisik yang melelahkan dapat menyebabkan penurunan kinerja tubuh. Ketika seseorang mengalami kelelahan maka akan terjadi penurunan kerja atau kemampuan seseorang dalam melakukan aktivitas fisik yang disebabkan oleh intensitas dan durasi sehingga menyebabkan terganggunya proses homeostasis. Salah satu indikator kelelahan adalah terjadinya peningkatan konsentrasi kadar asam laktat darah.
Berbagai bentuk aktivitas fisik yang dilakukan dengan intensitas tinggi dapat menyebabkan peningkatan kadar asam laktat dalam otot maupun dalam darah. Pada aktivitas submaksimal sistem energi yang paling dominan adalah sistem energi glikolisis anaerobic, sistem energi aerobic sangat minim. Aktivitas anaerobic yang berlangsung secara glikolisis anaerobic akan meningkatkan konsentrasi asam laktat dalam otot. Kadar asam laktat yang tinggi merupakan masalah dalam kinerja fisik yang dapat menyebabkan penurunan performa seseorang.

Selain model latihan, pemulihan yang disebabkan karena meningkatknya konsentrasi kadar asam laktat merupakan bagian yang paling penting. Mekanisme pemulihan asam laktat sangat dipengaruhi oleh aktivitas yang dilakukan 
setelah aktivitas tersebut. $\mathrm{Hal}$ ini akan mempengaruhi mekanisme keluarnya laktat dari otot ke darah, meningkatnya aliran darah, ambilan laktat oleh hati, jantung dan otot rangka. Kecepatan pengeluaran laktat akan mempengaruhi proses metabolisme berikutnya sehingga laktat dapat dimetabomisme kembali membentuk energi melalui Siklus Krebs. Peningkatan asam laktat dalam otot dan darah akan berdampak terganggunya kinerja sejumlah enzim yang bekerja pada $\mathrm{pH}$ netral atau basa sebagai katalis pada berbagai proses metabolism.

Peningkatan kadar asam laktat darah berlangsung pada periode pemulihan (recovery) setelah melakukan aktivitas berintensitas tinggi. Namun rumusan matematikanya belum diketahui secara pasti. Waktu paruh eliminasi laktat darah berkisar antara 10-15 menit. Namun, eliminasi laktat pada orang yang terlatih lebih cepat dari orang yang tidak terlatih. Bila kelelahan ini tidak ditangani dengan tepat dikhawatirkan akan merusak sel-sel dan jaringan tubuh lainya.

Pada olahraga prestasi pemulihan seorang atlet sangat penting terutama pada jenis cabang olahraga yang dalam satu hari melakukan pertandingan lebih dari satu kali ataupun dengan durasi yang lama misalnya pada cabang olahraga tenis. Maka dari pada itu, metode pemulihan merupakan salah satu hal yang harus diperhitungkan dengan tujuan mendapatkan performa yang baik pada pertandingan berikutnya. Sedangkan pada olahraga pendidikan (Penjas) metode pemulihan dilakukan dengan cara yang kurang tepat. Pada pembelajaran penjas hanya melakukan pendinginan yang sama setiap materi yang diajarkan, padahal, setiap materi intensitasnya tidak sama. Hal ini dikhawatirkan berimbas pada tingkat kebugaran jasmani siswa yang menurun sehingga siswa tidak dapat fokus melakukan kegiatan pembelajaran setelah pembelajaran penjas. Maka dari pada itu, baik olahraga prestasi maupun pada penjas diharapkan melakukan pemulihan dengan cara yang tepat, cepat dan mudah.

Perkembangan sport science, metode pemulihan setelah aktivitas fisik menjadi bahan yang menarik untuk dikaji. Pemulihan yang sempurna dilihat dari penurunan konsentrasi kadar asam laktat. Tujuannya adalah mengembalikan kondisi seseorang seperti sediakala atau kondisi dimana seseorang tersebut belum melakukan aktivitas fisik. Beberapa metode pemulihan yang baik, cepat dan mudah adalah metode pemulihan aktif dan metode pemulihan corstability. Metode pemulihan aktif merupakan metode pemulihan dimana seseorang yang telah melakukan aktivitas fisik melakukan aktivitas tidak hanya diam tetapi melakukan aktivitas dengan intensitas sangat ringan misalnya berjalan. Sedangkan metode pemulihan corstability merupakan metode pemulihan dimana seseorang melakukan aktivitas dengan intensitas sangat ringan dengan diselingi peregangan (stretching).

Penelitian ini bertujuan untuk Membandingkan metode recovery aktif dan corstability terhadap penurunan kadar asam laktat darah setelah melakukan aktivitas fisik submaksimal.

\section{METODE PENELITIAN}

Penelitian ini menggunakan metode penelitian eksperimental laboratoris. Sedangkan rancangan penelitian menggunakan Randomized Pretest-Postest Control Group Design. Hasil diambil dari perlakuan sesaat (respon akut). Sampel yang didapat dari penelitian ini adalah mahasiswa UKM Tenis Universitas PGRI Semarang yang berjumlah 18 orang. Kriteria Inklusi sampel penelitian ini adalah laki-laki berumur 21-23 tahun, mempunyai IMT yang normal (19-25). Kriteria eksklusi sampel penelitian ini adalah subjek mengalami sakit. Sedangkan kriteria Droup Out penelitian ini adalah kramp ketika malkukan treadmill, tidak berani untuk diambil sampel 
darah. Teknik pengelompokan terhadap sampel dilakukan dengan menggunakan teknik random sederhana yaitu 18 orang sampel yang terpilih dari populasi dibagi menjadi 2 kelompok dengan undian. Dimana kelompok 1 (K1) untuk kelompok metode recovery aktif sebanyak 9 orang dan kelompok 2 (K2) untuk kelompok metode corstability sebanyak 9 orang.

Penelitian ini dilaksanakan di Gardenia Swimming Poll \& Fitness Canter Kota Semarang. Penelitian ini dilaksanakan selama 3 hari dengan rincian pengambilan data secara bertahap. adalah

Alat yang digunakan dalam penelitian ini

a) Treadmill sebagai alat untuk aktivitas fisik.

b) Stop Watch digunakan untuk membatasi waktu pelaksanaan maupun perlakuan terhadap sampel.

c) Alat tulis untuk mencatat hasil perlakuan dan pemeriksaan pengukuran laktat darah.

d) Accutrend Plus untuk mengukur kadar laktat darah dari sampel.

e) Softclick dan jarum digunakan untuk menusuk jari tangan untuk mendapatkan sampel darah.

f) Alkohol, untuk mengoles daerah ujung tangan yang akan diukur darahnya dengan tujuan tidak terjadi iritasi (steril).

g) Kapas/tissue, untuk membersihkan darah setelah pengambilan kadar asam laktat.

h) Heart Rate Monitor (Polar) untuk kontrol denyut nadi.

\section{Pengambilan Data Pretest}

Data (laktat darah) pretest diukur sebelum melakukan aktivitas fisik yang sebelumnya dilakukan puasa selama 8 jam.

\section{Pengambilan Data Post Test}

Setelah melakukan aktivitas fisik submaksimal $80 \%$ selanjutnya segera (nol menit) dilakukan pengukuran kadar asam laktat. Selanjutnya diberikan perlakuan yaitu metode recovery aktif atau metode corstability selama 5 menit dan dilakukan pengukuran kadar asam laktat darah.

\section{Teknik Analisis Data}

Penelitian ini menggunakan teknik analisis data secara statistik deskriptif, uji normalitas, uji homogenitas, t-test Two sample assuming equal variances dengan taraf signifikan $5 \%$. Uji statistik menggunakan program SPSS secara komputerisasi.

\section{HASIL}

Hasil penelitian dapat ditampilkan dalam tabel sebagai berikut:

Tabel 1. Deskripsi data hasil pengukuran

\begin{tabular}{llll}
\hline K1 & & Mean & SD \\
\hline & Umur & 21.0 & 0,82 \\
\hline & BB & 68,8 & 2,28 \\
\hline & TB & 172,75 & 3,40 \\
\hline & Pre & 1,67 & 0,09 \\
\hline & Post 1 & 8,82 & 0,09 \\
\hline & Post 2 & 3,52 & 0,09 \\
\hline & Delta & 5,3 & 0,14 \\
\hline K2 & & Mean & SD \\
\hline & Umur & 21,5 & 0,58 \\
\hline & BB & 70,4 & 2,60 \\
\hline & TB & 172,25 & 2,87 \\
\hline & Pre & 1,72 & 0,95 \\
\hline & Post 1 & 8,77 & 0,95 \\
\hline & Post 2 & 4,45 & 0,13 \\
\hline & Delta & 4,32 & 0,05 \\
\hline
\end{tabular}

Ket:

K1: $\quad$ Kelompok Perlakuan Recovery Aktif

K2: Kelompok Perlakuan Recovery Corstability

BB: Berat Badan

TB: Tinggi Badan

Pre: Data sebelum melakukan aktifitas fisik

Post1: Data segera setelah melakukan aktifitas fisik

Post2: Data 5 menit setelah melakukan aktifitas fisik

Delta: Selisih Post 1 dan Post 2

Deskripsi analisis data hasil pengukuran menggunakan SPSS versi 21 didapat hasil yaitu antara kelompok menggunakan metode recovery aktif didapat umur dengan rata-rata 21,0 tahun, 
berat badan rata-rata $68,8 \mathrm{~kg}$, tinggi badan ratarata $172,75 \mathrm{~cm}$, kadar asam laktat darah sebelum melakukan aktifitas fisik dengan nilai rata-rata 1,67 mmol/L, kadar asam laktat segera setelah melakukan aktifitas fisik dengan nilai rata-rata $8,89 \mathrm{mmol} / \mathrm{L}$, kadar asam laktat 5 menit setelah melakukan aktifitas fisik dengan nilai rata-rata 3,52 $\mathrm{mmol} / \mathrm{L}$, dan selisih dari penurunan setelah melakukan metode recovery aktif dengan nilai rata-rata $5,3 \mathrm{mmol} / \mathrm{L}$.

Deskripsi data hasil pengukuran antara kelompok menggunakan metode recovery corstability didapat umur dengan rata-rata 21,5 tahun, berat badan rata-rata $70,4 \mathrm{~kg}$, tinggi badan rata-rata $172,25 \mathrm{~cm}$, kadar asam laktat darah sebelum melakukan aktifitas fisik dengan nilai rata-rata $1,72 \mathrm{mmol} / \mathrm{L}$, kadar asam laktat segera setelah melakukan aktifitas fisik dengan nilai ratarata $8,77 \mathrm{mmol} / \mathrm{L}$, kadar asam laktat 5 menit setelah melakukan aktifitas fisik dengan nilai ratarata $4,45 \mathrm{mmol} / \mathrm{L}$, dan selisih dari penurunan setelah melakukan metode recovery corstability dengan nilai rata-rata $4,32 \mathrm{mmol} / \mathrm{L}$.

Perubahan kadar asam laktat selama pemulihan dapat dilihat dari grafik sebagai berikut:

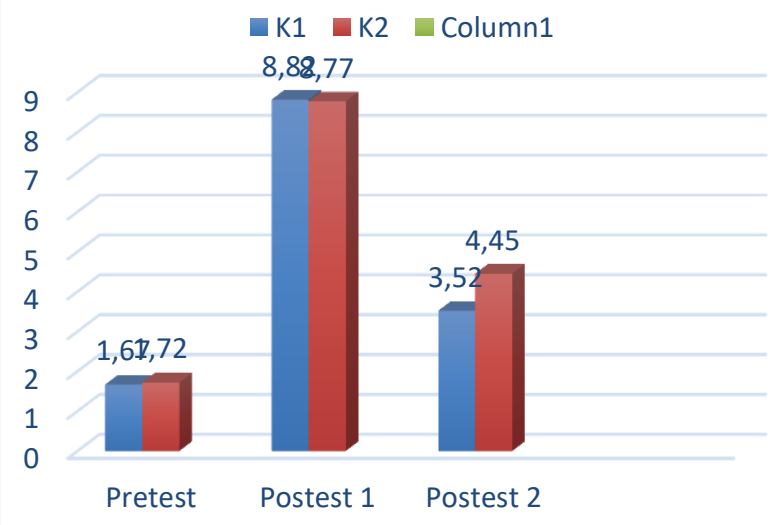

Grafik 1. Perubahan asam laktat selama pemulihan

Data hasil perubahan asam laktat darah seluruh kelompok setelah melakukan aktifitas fisik mengalami kenaikan yang signifikan. Kemudian terjadi penurunan 5 menit setelah melakukan recovery baik itu kelompok yang menggunakan metode recovery aktif maupun metode menggunakan corstability.

Nilai pretest 2 setiap kelompok mengalami penurunan kadar asam laktat darah kurang lebih 50 \% dari kadar asam laktat darah sebelum melakukan aktifitas fisik. Nilai pretest 2 merupakan nilai pembanding antara metode recovery aktif dan metode corstability yang didapat dari selisih postes 1 yang merupakan batas ambang laktat dan postes 2 yang merupakan hasil akhir yang diharapkan.

Sedangkan perbandingan delta K1 dan K2 dapat dilihat dari grafik sebagai berikut:

\section{Chart Title}

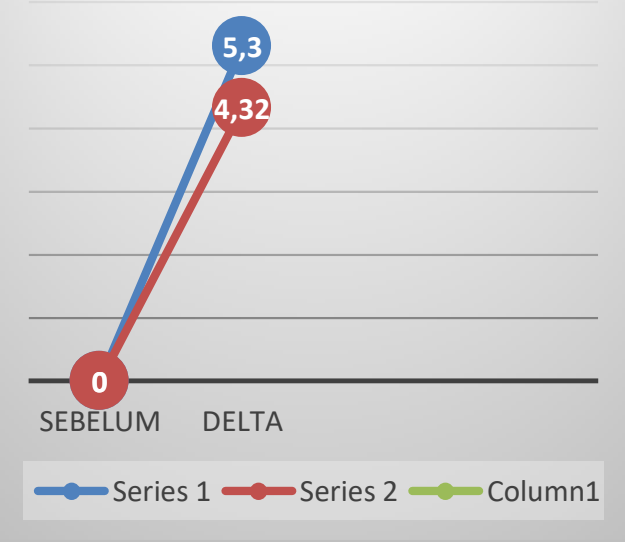

Grafik 2. Perbandingan hasil penurunan kadar asam laktat

Perbandingan hasil penurunan kadar asam laktat darah setiap kelompok dapat diperoleh dari hasil pengurangan postest 1 dikurangi posttest 2 yang merupakan tujuan dari keefektifitasan metode recovery. Semakin tinggi selisih berarti menandakan recovery semakin baik. Hasil diperoleh bahwa metode recovery aktif lebih baik disbandingkan dengan metode corstability. Data yang diperoleh adalah kelompok recovery aktif dengan selisih 5,3 $\mathrm{mmol} / \mathrm{L}$ sedangkan kelompok dengan metode corstability dengan selisih 4,32 $\mathrm{mmol} / \mathrm{L}$. 


\section{PEMBAHASAN}

Hasil penelitian menunjukan terjadinya penurunan kadar asam laktat darah pada pemulihan aktif lebih baik dari metode corstability. Hal ini karena aktivitas sederhana membantu sirkulasi darah yang bertujuan untuk mempercepat perpindahan asam laktat dari otot ke hati yang selanjutnya diubah menjadi glukosa melalui siklus cori. Pemulihan dengan intensitas rendah secara signifikan mengurangi akumulasi asam laktat yang tertimbun di otot dan memperdepat masa pemulihan.

Metode recovery aktif meningkatkan aktivitas $\mathrm{Ca}^{2+}$ yang signifikan yang kemudian membebaskan inhibisi yang sebelumnya sehingga enzim yang inaktif menjadi aktif kembali. Peningkatan ambilan $\mathrm{Ca}^{2+}$ dapat memulihkan gangguan yang ditimbulkan selama latihan dan meningkatkan pemulihan otot.

\section{SIMPULAN DAN REKOMENDASI}

Terjadi penurunan kadar asam laktat darah dengan menggunakan metode recovery aktif maupun corstability. Data yang diperoleh adalah kelompok recovery aktif dengan selisih 5,3 $\mathrm{mmol} / \mathrm{L}$ sedangkan kelompok dengan metode corstability dengan selisih $4,32 \mathrm{mmol} / \mathrm{L}$. Sehingga dapat ditarik kesimpulan bahwa metode recovery aktif lebih efektif digunakan dari pada metode corstability.

\section{UCAPAN TERIMAKASIH}

Terimakasih tentunya untuk program studi PJKR Universitas PGRI Semarang dan UKM Tenis Universitas PGRI Semarang yang bersedia membantu dan melancarkan penelitian ini. Penulis berterimakasih kepada pihak-pihak yang membantu secara langsung maupun secara tidak langsung.

\section{REFERENSI}

Ahmaidi S. (1996). Effect of Active Recovery on Plasma Lactate and Anaerobik Power Following Repeated Intensive Exercise. Med Sci Sport Exercise.

Ardle, M. and William, D. (1986). Exercise Physiology: Energy, Nutrition and Human Performance. Philadelphia.

Astrand P.O. \& Rodahl K. (1986). Text Book of Work Physiologi, second edition. Mc. Graw Hill Company.

Falk B. (1995). Blood Lactate Concentration Following Exercise: Effect of Heat Exposure and of Active Recovery in Heat-Aclimatized Subjects. International Journal Sport Medicine.

Fox E.L., Bowers R.W. and Foss M.L. (1993). The Physiological Basis of Exercise and Sport. USA: Wim. Brown Publisher.

Ganong WF. (1996). Fisiologi Kedokteran (terjemahan), Ed. 20. Jakarta: EGC.

Giriwijoyo S dan Muchtamadji MA. (2006). IImu Faal Olahraga: Fungsi Tubuh Manusia pada Olahraga untuk Kesehatan dan Prestasi. Bandung.

Gollnick P, Bayly MW, Hodgson RD. (1986). Exercise Intensity, Training, Diet and Lactate Concentration in Muscle and Blood. Medicine and Science in Sport and Exercise (18): 3:334449.

Guyton, AC and Hall. (2006). Text Book of Medical Physiology. Printed in China: W.B. Saunders Company.

Hind T, Mc Ewan and Perkes J. (2004). Effects of Massage on Limb and Skin Blood Flow After Quadriceps Exercise. Journal Med Sci Sport Exercise. Manchester Metropolitan University. Centre for Clinical and Biophysical Research into Human Movement. 1308-13. Janssen Peter GJM. (1993). Latihan-Laktat-Denyut Nadi(Training-Lactate-Pulse Rate). Oule Finland, Polar Electro. Penerjemah Pringgoatmojo dan M. Abdullah. 
Kent M. (1994). The Oxford Dictionari of Sport

Science and Medicine. Oxford: Oxford University Press.

Mattner U. (1988). Lactate in Sport Medicine. Germany: Boehringer Mannheim Gmbh.

Mayes PA. (2000). Harper's Biochemistry, $25^{\text {th }}$ edition. Edited by: Murray Rk, Graner Dk, Mayer PA, Rodwell VW. New York: Mc GrawHill, pp 149-159, 173, 177.

Mutalib P. (1993). Latihan Laktat Denyut Nadi. Jakarta: PT Temptin. Diterbitkan untuk KONI DKI Jaya.

Nancy A. Martin and Robert J. Robertson. (1998). The Comparative Effect of Sport Massage, Active Recovery and Rest in Promoting Blood Lactate Clearance After Supramaximal Leg Exercise. Journal of Athletic Training. Cenre for Sport Medicine. University of Shouthern Mississippi.

Nordheim K and Vollestand NK. (1990). Glycogen and Lactate Metabolisme During Low Intensity Exercise in Man. Acta Physiol Scand, 139 (3): 475-484.

Pramono, B. A., \& Sifaq, A. (2018). EFEK POSISI TUBUH SETELAH BERLATIH TERHADAP MASA PEMULIHAN. JSES: Journal of Sport and Exercise Science, 1(1).

Soekarman. (1991). Energi dan Sistem Energi Predominan Pada Olahraga. Jakarta: Inti Idayu Press.

Sudarso. (2004). Akumulasi Asam Laktat dan Kelelahan Selama Berolahraga. Jurnal IKOR (1): 2: 70-78.

Sugiharto. (2003). "Adaptasi Fisiologis Tubuh terhadap Dosis Latihan Fisik". Makalah disajikan dalam pelatihan senam aerobik. Malang: Laboratorium IImu Keolahragaan Universitas Negeri Malang.

Weltman A. (1998). Repeated Bouts of Exercise Alter the Blood Lactate RPE Relation. Medical Science Sport Exercise 30 (7). 